\title{
ARTICLES
}

\section{A NEW INSTITUTIONAL APPROACH IN EXPLAINING THE UNDERDEVELOPMENT OF ISLAMIC MICROFINANCE}

\author{
Yasushi Suzuki* \\ Mohammad Dulal Miah**
}

\begin{abstract}
The progress of Islamic microfinance is very slow despite the fact that mainstream Islamic finance has been growing marvellously. This paper explains the logic of underdeveloped Islamic microfinance, placing an emphasis on the supply side of funds. It argues that Islamic altruism appears to be dependent on reciprocity backed by mutual belief in the omnipotence and omniscience of the absolute power. Strong reciprocity however, may create a 'dilemma' - to be or not to be unconditional altruist - on the actors which might ironically drain the supply of funding to the poor. Evidence to support this hypothesis has been provided explaining some cases and other anecdotal facts. The research proposes that besides relying on actors' belief towards omnipotence and omniscience, appropriate safeguards against potential violation of cooperative and other Islamic social norms should be devised ex ante; otherwise Islamic microfinance is unlikely to thrive in the future.
\end{abstract}

Keywords: Islamic microfinance, reciprocity, cooperation, Islamic banks

\section{Introduction}

Islamic finance has been growing at a remarkable pace since its inception in the 1970s. According to Islamic financial services industry stability report 2014, assets with Islamic banks and Islamic banking windows grew at a compound annual growth rate of 40.3 percent between 2004 and 2011. Total asset of the industry estimated to be US\$1.8 trillion as at end of 2013. Furthermore, it has been predicted that Islamic banking assets will experience an average growth rate of 19.7 percent per annum until 2018 (King, 2015). This marvellous growth of Islamic finance however, seems not to be contributing much to achieve the motto of financial inclusion towards financing unbanked and financially stranded segments of the population. Islamic financial institutions, besides their typical role of providing finance following Shari'ah principles, are also expected to make a positive contribution in poverty alleviation by fulfilling the socioeconomic objectives of 'social justice' 
in accordance with the objectives of Shari'ah. In practice, mainstream Islamic financial institutions, like their conventional counterparts, are reluctant to provide finance to small and microenterprises. In this circumstance, Islamic microfinance can be a critical source of finance for those small entrepreneurs who are untouched by Islamic banking system and also shy in accepting finance from conventional microcredit providers who are dealing with interest.

An analysis on the demand and supply of Islamic microfinance reveals a yawning gap between them. Currently, there are 650 million Muslims living on less than $\$ 2$ per day and majority of them prefer to be included under the umbrella of Islamic finance. For instance, a number of IFC-commissioned market studies in Afghanistan, Indonesia, Syria and Yemen suggests a strong demand for Islamic microfinance products: there are many Muslim clients who use conventional products but are ready to switch once Islamic finance is at their reach (Karim et al., 2008). Another survey referred by UNDP (2012) indicates that 80 percent of the Muslim respondents claimed to prefer Islamic products to conventional products, while 45 percent showed their preference even if cost of fund provided by Islamic microfinance is higher than conventional microfinance. The survey further shows that 85 percent of the current borrowers from conventional microfinance institutions (MFIs) admitted that they would switch to Islamic products if available. This provides with the evidence that the Muslim clients are concerned about Islamic financial products which aim to fulfil the socioeconomic objectives of social justice in accordance with the objectives of Shari'ah.

However, the overall supply of Islamic microfinance products is still quite small compared to the demand. An estimated 255 financial service providers worldwide offer Shari'ah-compliant microfinance products to approximately 1.28 million clients. Of them, approximately 82 percent reside in only three countries: Bangladesh, Sudan, and Indonesia. In Bangladesh, Islamic microfinance remains very small in comparison with the conventional one. As of 2007, the top 535 NGOs and MFIs distributed approximately US\$10,690.86 million to 39 million beneficiaries of which Islamic MFIs represent only 1.26 percent (UNDP, 2012). In the context of Sudan, Eissa (2013) reports that except three state-owned banks, the disbursement of microcredit is negligible against the mounting demand for it. Khaled (2011) provides further evidence stating that even major microcredit institutions in Sudan have failed to reach beyond 10,000 active clients after 10 years in operation whereas their conventional counterparts are growing rampantly. The scenario is same in Indonesia as well. Karim et al. (2008) show that in 2006, Islamic financing instruments comprised only 2 percent of outstanding microfinance loans in Indonesia. In addition, the average outreach is merely 2,400 clients. The story is similar in other Muslim countries in the world. In Pakistan, for instance, there are 1,613 branches of the microfinance services to the poor 
and the active borrowers are around 2 million (Arif and Farooq, 2011). Taking into account the magnitude of more than 45 million poor households, the level of micro-financial deepening is still low. Besides, the Pakistani Islamic banks - 6 licensed Islamic banks and 12 conventional banks with more than 330 branches operating as of 2007 - are not providing microfinance services. Though some nonbank Islamic institutions are providing the micro-credit services, their outreach is very limited in the country. In sum, the overall progress of Islamic microfinance is still very limited. This leads us to ask a host of important questions:

I. How can we explain the underdevelopment of Islamic microfinance?

II. Is there sufficient supply of funds available for Islamic MFIs like their conventional counterparts?

III. Despite Islamic tradition and teaching about social equality and justice, why Muslims hesitate to achieve these objectives through financing microenterprises?

IV. What needs to be done for a rigorous Islamic microfinance sector?

The paper attempts to answer these questions. In so doing, it draws the following hypotheses:

Hypothesis I: shortage of funds is the critical constraint to a thriving Islamic microfinance sector.

Hypothesis II: 'reciprocators' dilemma' - to be or not to be unconditional altruists for the poor - drains the supply of funding to the poor.

The above hypotheses are then tested analysing the liability side of Islamic microfinance institutions to unveil if there is any shortage of fund as a possible obstacle that inhibits the progress of the industry. In addition, the research draws on the theoretical contributions of the New Institutional Economics (NIE) and applies some of these contributions to analyse the logic of underdeveloped Islamic microfinance. The paper has been structured as follows: section two describes the concept of Islamic altruism citing various Qur'anic verses and Hadiths. This section also explains the idea that unconditional altruism can create the reciprocator's dilemma which can contribute to a slow growth of the sector. Section three highlights a case, Rural Development Scheme (RDS) of Bangladesh, to show the contribution of one of the largest Islamic microfinance providers towards financing poor Muslims. Section four connects the reality RDS to reciprocators' dilemma with the help of an analysis of stag hunting game. This is followed by a conclusion and policy recommendations.

\section{Islamic altruism and reciprocity}

Green traces the origin of the term "altruism" to August Comte who coined the 
term in the nineteenth century from the Latin word "alter" which means "other" or "care for others". In commensuration with this concept, Green (2005) defines altruism as an intentional action which is undertaken for the welfare of others without expecting any benefits or in some cases the actor might suffer a loss. Homerin (2005) translates the Arabic word Al-Ghayriah from the word Ghayr, meaning "others". However, the Qur'anic meaning of Ghayr tends to indicate "others" in general although it includes the intention of favouring "others" than the self. Homerin (2005) further argues that the closest term to "altruism" in Arabic can be found in the Mediaeval Sufi term "Ithar" which means "preferring the other to the self" (Homerin, 2005:84). Ithar is used in the Qur'an to mean charity (Yosoff, 2014). Likewise, scholars endorse charity to indicate altruistic behaviours of agents (Khalil, 2004). Hammond (1975:115) clears the concept “... altruism can be invoked to explain any charitable behaviour we may observe. But it is not quite obvious that altruism must be invoked to explain all charitable behaviour." For Hammond (1975) other than pure altruism, some charities are driven by egoism - a condition in which the altruist believes that his current altruistic actions would return in the future while in need. Or in the view of Fong (2007) the former is unconditional altruism while the latter is reciprocal altruism. All these views conform to the idea that altruism can be equated with charity in the context of Islam.

Many scholars including Mawdudi (2011) and Naqvi (2003) point out that the Islamic right of the poor to receive their share in the wealth of the rich strengthens altruistic behaviour significantly in running efficiently and equitably an essentially individualistic economy. To begin with, we look at the 'altruism' of the Madinah Muslims, praised by Allah in the Qur'an, which was so great in its scope and impact:

And (in this wealth there is also a share) for those (the Helpers) who had settled in the city (of Madinah) and had embraced the Faith before these (refugees arrived there). They love those who migrated to them for refuge and (who) even though poverty be their own lot, found no desire in their hearts for that which is given to them (refugees) but they gave them (refugees) preference over themselves. And (bear in mind that) those saved from the covetousness of their souls are the ones to achieve the goal (Qur'an 59: 9) ${ }^{1}$.

In the Muslim society, there is the powerful concept of Allah's ownership of all wealth and that human beings are mere 'trustees' of this wealth (Qur'an 3:180, 57:10). As is summarised in Naqvi (2003: 105), what this means is that the individual's right to spend his wealth is limited in several ways: (a) he must spend it according to Divine wishes (Qur'an 57: 10), (b) he cannot hoard it, especially when 
there are urgent social needs to be met (Qur'an 3: 180), (c) he must give it to the poor not as charity but as a matter of the latter's acknowledged right in his wealth (Qur'an 70: 24-25), and (d) he must spend wealth only in moderation because being spendthrift is both a social waste and a cardinal sin (Qur'an 17:26-27).

The Holy Qur'an further, unambiguously states that the poor have a due share in the wealth of the rich. Naqvi (2003) elaborates this notion in that "it is motivationally rational for a person to sacrifice his selfish interests because in Islam (a) "success" is measured in terms of one's distance from greed and avarice; or (b) making a sacrifice in this world enhances the expected reward in this world as well in the hereafter". In parallel, the role of waqf is emphasised as an important contributor to societies: $w a q f$ is considered as retention of a property for the benefit of a charitable or humanitarian objective, or for a specified group of people such as members of the donor's family. The global waqf will focus on three basic activities: on-going charity (sadaqa jariyah), education and family waqfs (Çizakça, 2011). On-going charity can be interpreted as a poverty alleviation mechanism. Qur'an postulates the virtue of spending in philanthropic motive:

Never shall you attain the highest state of virtue unless you spend (in the cause of Allah) out of that which you love; and whatever you spend. Allah, indeed, knows it well (Qur'an 3:92).

The above discussion postulates that Islamic altruism for realising social and economic justice through eradicating poverty is comprehensive and greater in scope. For example, even the Rawlsian Difference principle which regulates inequality and explicitly requires the rich to help the poor on a priority basis " ... does not include in the rich man's wealth the right of those who cannot participate in market exchange (Naqvi, 2003:107). Naqvi (2003:107) further notes "Western theological systems are generally ambiguous about recognising the poor's right". Moreover, in the tradition of western political philosophy, altruism itself depends on recognition of the reality of the other persons, and on the equivalent capacity to regard oneself as merely one individual among many (Nagel, 1970:3). In contrast, Islamic altruistic behaviour appears to depend on reciprocity backed by mutual belief in the omnipotence and omniscience of the absolute power. Furthermore, Qur'an's propagation about the poor's right in the wealth of the rich is a unique institutional structure which creates Islamic reciprocity and is helpful to supply the fund for those small and microenterprises that face difficulties in fund-raising.

We should note that, as is pointed out by Samuel Bowles, not only unconditional altruists but also 'strong reciprocators' may support redistribution to the poor. "Altruism is a widely discussed and important motive for assistance to the poor. But strong reciprocity provides a quite different perspective. Strong 
reciprocators wish to help those who try to make it on their own but who, for reasons beyond their own control, cannot, and they wish to punish, or withhold assistance from, those who are able but unwilling to work hard or who violate other social norms" (Bowles, 2012: 145-6). Bowles refers to 'strong reciprocity' which is a propensity to co-operate and share with others similarly disposed, even at personal cost, and a willingness to punish those who violate co-operative and other social norms, even when punishing is personally costly and cannot be expected to result in net personal gains in the future (Bowles, 2012: 131). He refers to a report in which many people (81 percent of survey respondents in the report) favour public funding for child care if the mother is a widow who is trying to support three children, while only a few (only 15 percent in the report) favour public funding when the mother has never married and is not interested in working. Bowles is concerned about strong reciprocity as driving force of making people willingly help the poor, but withdraw support when they perceive that the poor may cheat or not try hard enough to be self-sufficient and morally upstanding. Or in other words, strong reciprocity while driving actors towards helping others responding to their social obligation is not ready to tolerate opportunistic behaviour of entrepreneurs.

The New Institutional Economics provides an important explanation in the question of opportunism and its complementary element, trust. The school argues that the risk of opportunism can be reduced by mutual trust (Williamson, 1985). Trust has been referred to as "attitudes and behaviour which indicate that each person is willing to rely on the other to act fairly and to take into account the other's welfare", as "solidarity", and as "a belief in future harmonious affirmative cooperation" (Cohen and Knetsch, 1992). Contract negotiations and performance will likely take place more effectively if trust is present and is generated by the process (Cohen and Knetsch, 1992). Fukuyama (1995), referring to what the sociologist James Coleman has called 'social capital', argues that the ability of people to work together for common purposes in groups and organisations and their ability to associate with each other depends on the degree to which communities share norms and values and are able to subordinate individual interests to those of larger groups. Trust evolves from these shared values (Fukuyama, 1995). One of the invaluable insights of Francis Fukuyama and Kenneth Arrow (1974) is that trust has a large and measurable economic value and has an important bearing on economic organization. "Ethical elements enter in some measure into every contract; without them, no market could function. There is an element of trust in every transaction; typically, one object of value changes hands before the other one does..." (Arrow, 1974: 24).

In general, opportunism in terms of pursuing self-interest with guile involves subtle forms of deceit and refers to the incomplete or distorted disclosure of 
information, especially to calculated efforts to mislead, distort, disguise, obfuscate, or otherwise confuse (Williamson, 1985: 47). However, since operationalising trust, no matter how it is defined, has proved inordinately difficult (Williamson, 1985: 406), the empirical analysis of the variable is still limited. Arrow insists that the efficacy of alternative modes of contracting and monitoring would vary among cultures because of differences in trust. To some extent, cultural factors are related to the degree of trust relations. However, we would say that the degree of trust even in a particular culture or society could rather vary. "Most of us operate in some middle realm where we admit social claims, sometimes forget about them for long stretches of time as we go about our daily private role, sometimes rise to an occasion, sometimes fall miserably short, as we assert our individuality in contexts that are not totally appropriate" (Arrow, 1974).

From the Williamsonian 'opportunism' perspective, we may say that the cooperative mode of economic organisation, where trust and good intentions are generously imputed to the membership, has its weakness in being endowed with few organisational responses to the debilitating effects of opportunism. For Williamson (1985: 64-5), "such organisations are easily invaded and exploited by agents who do not possess those qualities". Transactions that are subject to ex post opportunism will benefit if appropriate safeguards can be devised ex ante (Williamson, 1985: 48). We should note that, in other words, if safeguards are not sufficiently devised ex ante, opportunism would possibly emerge as a troublesome source of behavioural uncertainty in economic transactions. While, Islamic altruism and reciprocity towards the poor may, in theory, contribute to facilitating Islamic microfinance, lack of information about the efforts and sincerity of agents is likely to inhibit the process in the same way. To some extent, microfinance is still seen as a philanthropic activity rather than a business enterprise because profit motive of microfinance is depressed by the fact that managing small transactions is intrinsically costly, while screening and monitoring microenterprises is extremely difficult.

We argue that a way out of this dilemma - to be or not to be altruistic in the context of Islamic microfinance - can be devising some mechanisms ex-ante that will create a sense of understanding that agents will not behave opportunistically. By the same token, Naqvi (2003) points out that public policy is required to assure the altruistic individual (one who is not inclined to free-ride) that his contribution will not go to waste and that others in society will not be allowed by the government to withhold their contributions.

An excess insistence on altruism can create a permanent tension between what a Muslim society is required to do and what eventually gets done in practice. Indeed, there is a real danger that if moral 
perfection is demanded at all times, then the entire social system will become dysfunctional for want of the required supply of altruism. Thus, in general, appropriate public policy must keep a balance between self-interest behaviour and moral imperative because the principles of altruism and exchange are both mutually supportive as well as antithetical (Naqvi, 2003: 131).

From the Muslim perspective, there is no agency problem between the absolute existence as the principal and its followers (including fund providers, lenders and borrowers) as the agent, because the followers retain their firm belief in the omnipotence and omniscience of the absolute existence. As mentioned earlier, Islamic altruistic behaviour appears to depend on reciprocity backed by mutual belief (among the followers) in the omnipotence and omniscience of the absolute power. At the individual level, the prospect of accountability on the Day of Judgment would bring positive behavioral changes. However, the current-life problem in microfinance is ensued from the fact that nobody knows the judgment on the others; in other words, nobody on earth precisely knows the scale of spiritual belief of others on the Day of Judgment. Thus, Muslim principal (particularly fund providers) is exposed to higher agency risk and more so because the Muslim fund providers have the divine obligation to share risks in enterprise under the PLS scheme as well as to share a portion of income with the poor or the entrepreneurs who face difficulties in fund-raising. This altruistic or reciprocal behavior is always monitored by the absolute existence. This structure may cause a dilemma in the Muslim agents as well. Unless appropriate safeguards and rules for protecting the right of the principal can be devised an ante, it makes sense that potential moral hazard or possible opportunistic behavior in the agent (particularly borrowers) would make the principal (particularly fund providers) hesitate to share risks in enterprise if he/she is not unconditional altruist. At present such safeguards in this purpose are rare. As a consequence Islamic microfinance is still underdeveloped. The following case reveals this scenario highlighting the problems of scarcity funds.

\section{The Case of Rural Development Scheme in Bangladesh}

Bangladesh is a poverty stricken country where majority of the population lives in abject poverty. Poverty eradication is the primary focus of the country's socioeconomic and political agenda. The evolution of microfinance in Bangladesh is the result of this strategy. In other words, Bangladesh can be viewed as the synonym for microcredit due to the sector's rapid expansion over the last few decades. Basically two direct channels are providing microcredit in Bangladesh 
- microfinance institutions (MFIs) which are the main direct providers and nongovernment organizations (NGOs), and apex lenders including bank and nonbank financial institutions. As of June 2013, total loan outstanding of microcredit institutions amounted to Bangladeshi Taka (BDT, the currency of Bangladesh) 341 billion and savings BDT 226 billion. The total client base of the sector is estimated to be 33 million. Total loan outstanding of the sector grew at an average 16 percent annually from 2009 to 2013 whereas savings increased by 17 percent per annum at the same time. Despite this laudable endeavour, microcredit outreach to the poor is still far from the target. Studies show that more than 60 percent of all poor households have been found one way or other involved in micro-credit programs in the country (Ahmad, 2007). The scenario would be more depressing if we consider the fact that one borrower taking loan from more than one MFIs and the extent of overlapping may be as high as 40 percent (Imai and Azam, 2010).

One of the critical reasons of not many poor coming under the umbrella of conventional microfinance in Bangladesh is the religious belief. Islam is the official religion in Bangladesh and it is the third largest Muslim country in the world in which 90 percent of the population belongs to the Muslim faith. A large proportion of the poor is practicing Muslims, and is unable to take advantage of traditional microfinance contracts which involve the payment of interest. In response to this market niche, some MFIs have started providing microcredit to the poor following the Islamic principles However, the outreach of Islamic microfinance is very low worldwide let alone Bangladesh. There are many smallsized Islamic MFIs rendering their services to the poor in Bangladesh. Notable among them is the Rural Development Scheme (RDS) mechanised and controlled by the Islamic Bank Bangladesh Ltd. (IBBL). IBBL started the first interest free bank not only in Bangladesh but also in South Asia and introduced the RDS in 1995 as part of its corporate social responsibility (IBBL is considered now one of RDS main financing channels) to support the government in addressing the high rates of rural poverty, and to tackle the gaps associated with government program that failed to target the poor. Its main goal is to create employment opportunities for the poor and alleviate poverty through income generating activities by adopting Islamic microfinance products (UNDP, 2012). It is reported that RDS alone serves 67 percent of the total Islamic micro-finance market in Bangladesh (El-Zoghbi and Tarazi, 2013).

The RDS program is styled in accordance to Grameen Bank concept except the fact that the former uses Islamic modes of investment based on the profit and loss sharing methodology whereas the latter uses conventional practice. As per the RDS micro-financing model, the bank does not issue the agreed upon loan amount to customers in cash, but rather delivers goods to the customers 
ensuring that lending is invested in income generating activities. Investment financing starts after eight weeks of observing the group members in terms of regular attendance to the weekly group meetings and center meetings. At the group and center meetings, members are offered support services such as skill training, environment awareness, and entrepreneurship development to ensure the success of the potential small and medium entrepreneurs. This is offered to ensure that potential beneficiaries are successful in starting and managing their new investment. During the eight week process the field officers in collaboration with the investment committee of the branch carefully review all the investment applications. Upon the approval of the applications, investment products (not cash) are handed over to the clients. The initial investments start around Tk. 10,000 (approximately USD 145) and based on good repayment, thresholds increase by Tk. 2,000 to Tk. 5,000 in every succeeding term depending on the sector of investment. The rate of return (based on profit and loss method) is at 12.5 percent, however timely repayment is rewarded by a 2.5 percent rebate, thus a successful member will pay 10 percent of his or her profit to the bank. This rate of return makes it lower than any rate offered by any conventional MFI in Bangladesh.

Members of the center also have to open a Mudaraba savings account and are required to deposit Tk. 20 per week. Savings however can be withdrawn once members have fulfilled their liabilities toward the bank. This ensures the sustainability of the fund. And to encourage the act of Zakat, members are encouraged to deposit a minimum of Tk. 5 per week to the Quard El Hasan, which is an interest-free fund given to the extremely poor, for members who are not able to make their timely payments or toward the rural development of the community (for instance, building and installing latrines, tube wells etc.). The receiver of the Quard El Hasan is only liable for the repayment of the principle. This innovative approach encourages the act of giving and ensures that the extremely poor are included in the program to make them self-reliant and productive in the community. This kind of operational mechanism has proved to be very successful in benefiting many of the rural poor. RDS's current repayment rate is 99 percent, making this scheme one of the most successful schemes in Bangladesh (UNDP, 2012). Despite all these effort, Islamic microfinance remains very small in comparison with the conventional MFIs in Bangladesh (Table 1). 
Table 1: Selected indicators of RDS

\begin{tabular}{|l|l|l|l|l|l|l|}
\hline & \multicolumn{3}{|c|}{ As of December 2012 } & \multicolumn{3}{c|}{ As of December 2013 } \\
\hline & RDS & \multicolumn{1}{|c|}{ All MFIs } & $\begin{array}{c}\text { Share of } \\
\text { RDS }\end{array}$ & RDS & All MFIs & $\begin{array}{c}\text { Share of } \\
\text { RDS }\end{array}$ \\
\hline $\begin{array}{l}\text { No. of } \\
\text { Branches }\end{array}$ & 207 & 17,890 & $1.16 \%$ & 240 & 18,332 & $1.31 \%$ \\
\hline $\begin{array}{l}\text { No. of } \\
\text { Employees }\end{array}$ & 2,154 & 230,522 & $0.93 \%$ & 2674 & 233,901 & $1.14 \%$ \\
\hline $\begin{array}{l}\text { No. of Active } \\
\text { Members }\end{array}$ & 733,520 & $33,714,959$ & $2.18 \%$ & 836,227 & $33,673,341$ & $2.48 \%$ \\
\hline $\begin{array}{l}\text { No. of } \\
\text { Borrowers }\end{array}$ & 474,766 & $26,895,515$ & $1.77 \%$ & 532,235 & $26,728,034$ & $1.99 \%$ \\
\hline $\begin{array}{l}\text { Loan } \\
\text { outstanding } \\
\text { (in MI Taka) }\end{array}$ & $10,390.71$ & $325,051.12$ & $3.20 \%$ & $13,730.92$ & $365,981.54$ & $3.75 \%$ \\
\hline $\begin{array}{l}\text { Net Savings } \\
\text { (in MI Taka) }\end{array}$ & $3,322.52$ & $163,439.87$ & $2.03 \%$ & $4,377.98$ & $199,977.66$ & $2.19 \%$ \\
\hline $\begin{array}{l}\text { Microcredit } \\
\text { as \% of Bank } \\
\text { credit }\end{array}$ & 0.33 & 11.76 & $2.81 \%$ & 0.32 & 9.78 & $3.27 \%$ \\
\hline
\end{tabular}

Source: Authors' calculation based

Bangladesh Microfinance Statistics (BMS), 2013

As of December 2013, a total of BDT 325 billion (roughly US \$4.17 billion) amount of loan disbursed to about 27 million borrowers by 550 microfinance institutions which was 3.75 percent higher than the figure in 2012. However, the portion of Islamic microfinance compared to the total scenario shows a very depressing result. For instance, RDS (which serves two third of the total Islamic microfinance market in Bangladesh) represented only 3.2 percent of the total market of microfinance in 2013. In terms of borrowers, RDS accounted for only 1.77 percent of all microfinance borrowers in 2013. While total microfinance in the country represents approximately 12 percent of bank credit, RDS accounts for only 0.33 percent of it. This profile shows that the deepening of Islamic microfinance in Bangladesh is very miniscule even though the country is featured by majority of Muslim population and top Islamic microfinance provider in the world. In practice, the demand is there but the supply of sufficient funds to meet that demand is absent. 
Needless to say, microfinance programme requires high operational cost which creates a downward pressure on the profitability and sustainability of these types of institutions. It is reported that the net profit of RDS as percent of the investment income has been decreasing. In 1996, that figure stood at 62.91 percent and has been gradually decreasing to 0.24 percent in $2008,7.88$ percent in 2009. The leading microfinance institution in Bangladesh, Grameen Bank, charges an annual interest rate of 20 percent on its main credit product; this rate however, is below the cost recovery level. In the case of Islamic microfinance, the product category is such that requires higher transaction cost than their conventional counterparts. For instance, in Murabaha or Ijara transactions, the provider of funds purchases a commodity (such as equipment or inventory) and resells or leases it to the user with a markup. Islamic MFIs may benefit from cheaper prices on the wholesale market, but the costs associated with purchasing, maintaining, selling, or leasing a commodity (such as a sewing machine) are expensive.

The problem of high operational cost can be tackled by capitalising on economies of scale through expanding the scope of their services. This requires permanent and stable sources of finance for these institutions. In reality, Islamic microfinance institutions in Muslim majority countries suffer from lack of funding. An analysis of sources of funds for microfinance institutions in Bangladesh reveals that members' net savings contribute 44 percent of the total funding whereas institutions' own funds contributes about 14 percent; surplus income and bank loans contribute roughly around 9 percent each (BMS, 2013). Among outside sources, donor fund from both multilateral and national agencies is a contributing source for conventional microcredit providers. However, for Islamic microfinance institutions, fund flowing from outside sources is further restricted by principle of interest-free transaction. There is a lack of knowledge on the concept among many donors. As a result, they most likely show no interest in funding such programs. Commercial Islamic banks, which are much more familiar with Islamic financial products, such as IBBL, play an important role in supplying funds to those microfinance institutions. However, for programs to be sustainable in the long-run adequate funding support and commitment will be required. Perhaps, IBBL was able to provide funding toward RDS at the beginning. But the operational cost of RDS increases drastically with the increase of its coverage. As a private bank, IBBL has the resources for its commercial means to fund such a program, however for MFIs wanting to emulate this program, they will require funding from governments, donors and from the private sector in order to be sustainable (UNDP, 2012). To make this into reality, mechanisms are to be devised for overcoming the problem of reciprocator's dilemma. 


\section{Reciprocator's dilemma}

In Bangladesh, a market positioning is seen when they find that the Islamic banks are engaged in providing 'non-participatory' financing mainly to the Muslim traders and merchants in the urban area. Due to the scarcity of 'risk' fund in their capital structure and the opportunity to capture a certain promised returns from non-participatory financing, the Islamic banks' strategy in asset portfolio management - the so-called "murabaha" syndrome - makes sense. However, the Muslim community faces an institutional failure to mediate the risk fund into a new venture or a large scale project by SMEs which need the risk diversification among the society. The pertinent question is how can the Islamic banks possess a diversified base of depositors who absorb the associated potential loss, which encourages the banks to engage more in participatory financing? This is an important challenge not only to the Islamic banks, but also to the Bangladeshi economy as a whole.

Conventional microfinance and Islamic banking are not always complementary in Islamic economies. In Bangladesh, for instance, there is a significant difference between these two systems - the mode of Islamic banking and the Grameen Bank (GB) mode of microcredit - when it comes to the target group and the cliental-base. The GB microcredit targets the marginalised poor of rural areas of Bangladesh, its members and borrowers lay at the bottom of the economic ladder in the society. More importantly, 98 percent of GB members are rural women. It is a kind of organisation where extra income, wealth, and land become disqualifications for borrowing and membership. Also, GB offers microcredit on the basis of group collateral, whereby no asset underlies against the lending. On the other hand, the Islamic banking operations in most cases are still confined to urban or semi-urban areas and their target groups are different than those of the GB. Yet, the portfolio of lending of the Islamic banking is dominated by financing like Murabaha and Ijara, which are backed by assets. From institutional viewpoint, they are essentially not competitors. Rather, GB borrowers after graduation from their below poverty status to above poverty may complement the Islamic banking activities at a distant end. The recent involvement of one of the Islamic banks with the development of small entrepreneurs in Bangladesh by adopting the operating system of GB in accordance with the framework of Islamic Shari'ah gives an indication about the possible complementarity of the two systems of banking.

Can we accept such a hypothesis that Islamic banking is fundamentally concerned about the merchants in the urban area, less concerned about the farmers and small manufacturers in the rural area? Islam, a religion born in the Arabian Desert, where trade constituted the most important, "perhaps even the 
sole economic activity, favours merchants, property rights, free trade and market economy" (Çizakça, 2011: xv). In this context, Islam is called as the religion for merchants (Ayub, 2007; Çizakça, 2011). The business ethics in the Islamic mode of transactions are related to the civilised urban way of life at the birth of Islam. The holy Prophet had spent half of his life working as a merchant in Mecca, where the urban culture flourished and the values for facilitating fair transactions among the merchants in equal positions were shared. The Prophet mentioned that trade constituted nine-tenth of the livelihood of early Muslims. In fact, of the four righteous Caliphs, Abu Bakr was a cloth merchant and Uthman was an importer of cereals (Çizakça, 2011: xiv).

The values being shared among merchants have developed the concept of business and trade, while Islam restrains the freedom to engage in business and financial transactions on the basis of a number of prohibitions, ethics and norms. It is widely known that the prohibition of riba (usury), gharar (uncertainty) and maisir (gambling) is the most strategic factor that defines invalid and voidable contracts and demarcates the overall limits which should not be crossed (Ayub, 2007: 12). The prohibition of gharar in speculation is considered as the wisdom for minimising the potential periodic financial disaster (Suzuki, 2013). In parallel, the prohibition of gharar as well as the profit-loss sharing (PLS) framework may have given Islamic banks a dilemma of the so-called 'murabaha syndrome' (concentration of conservative credit portfolio on asset-backed transactions at mark-up pricing). How can we expect the Islamic banking to contribute to the development of microfinance in the primary and secondary industries? Yumna and Clarke (2011) introduce Asyraf Wajdi Dusuki's argument such that group based lending mechanism is not alien in Islam as it has been known by the concept of As Sabiya which shares the positive values such as teamwork, sense of belonging, cooperation and trust. In spite of that Islamic MFIs have failed to realise advantages from these religious institutions.

We can resort to NIE to draw a logical explanation of this anomaly. One of the salient contributions by NIE is to support the proposition that effective contracting is dependent upon institutions in terms of "rules that constrain economic behaviour", including informal or intangible institutions such as religious, culture and customary practices. Although there should not be an overemphasis on the cultural factors, it can be argued that the unique institutional structure which creates Islamic altruism and reciprocity may enhance the supply of Islamic microfinance, but simultaneously, may cause opportunistic behaviour, consequently leading to the drain of the capital for small and micro-enterprises. In particular, strong reciprocators would fall into a dilemma - to be or not to be unconditional altruists for the poor. 
The concept of reciprocators' dilemma is related to a dimension of 'assurance game' which is also commonly known as 'stag hunt' in the game theory. The French philosopher, Jean Jacques Rousseau, presented the following situation. Two hunters can either jointly hunt a stag (an adult deer and rather large meal) or individually hunt a hare (tasty, but substantially less filling). Hunting stags is quite challenging and requires mutual cooperation. If either hunts a stag alone, the chance of success is minimal. Hunting stags is most beneficial for society but requires a lot of trust among its members. Each can individually choose to hunt a stag or hunt a hare. Each player must choose an action without knowing the choice of the other. If an individual hunts a stag, he must have the cooperation of his partner in order to succeed. An individual can get a hare by himself, but a hare is worth less than a stag. In the stag hunt, there are two pure Nash equilibria; when both players cooperate and both players defect. An example of the payoff matrix for the stag hunt is described in table 2 .

Table 2: The payoff matrix of stag-hunt game

\begin{tabular}{|c|c|c|}
\hline Player $2 \quad$ Player 1 & Corporate (stag) & Defect (hare) \\
\hline Corporate (stag) & $(2,2)$ & $(0.1)$ \\
\hline Defect (hare) & $(1,0)$ & $(1,1)$ \\
\hline
\end{tabular}

Assume that there are two projects; one project is planned by a microenterprise or a start-up, the other is a murabaha project. The success of the former project would contribute to the society in terms of alleviating poverty and incubating innovative entrepreneurs (stag), though the probability of success is relatively low. The success of the latter project would less contribute to the society (hare), though the probability of success is relatively high. Also assume that there is a Muslim investor (player 1) who is ready to finance the poor or innovative microenterprises, but is worried about the potential opportunistic behaviour of the borrower. The best payoff is that the investor (player 1) would invest in microfinance upon a belief in the commitment by the borrower (player 2) to pay best efforts for the success of the project - represented by the $(2,2)$ payoff in the matrix. If the investor instead of investing in microfinance prefers murabaha project he would get a fixed return from murabaha, but there would be no chance of the stag project to be materialised for the borrower $(1,0)$. Even though the investor invested in microfinance, if no borrower challenges to implement the stag project or if the borrower shirks paying best efforts for the success of the project, the investor would get nothing $(0,1)$. Most likely, the investor with reciprocators' dilemma would hesitate to finance for the poor, though he/she is 
ready to do for the poor, consequently incubating only murabaha projects by the enterprises who possess assets for funding $(1,1)$.

We assume that faith communities and organiations have played an extensive and important role in supporting microfinance and sustaining economic development efforts (Looft, 2014). There is a growing tendency to view zakat as a source of funding for microfinance. Zakat funds appear ideally suited to support Islamic microfinance as a poverty alleviation strategy (Karim et al., 2008; Yumna and Clarke, 2011). However, Yumna and Clarke (2011) point out that although zakat is compulsory charity in Islam to fight against poverty, the awareness of Muslim of paying zakat is not so high. They report that BAZNAS, the largest zakat institution in Indonesia, only collected US\$ 2.6 million in 2010, where the national potency of zakat on household income reaches US\$ 61 trillion (they refer to the data from FEM Institut Pertanian Bogor Indonesia 2011). Given this scenario, the zakat fund would not be reliable as a source of funding. Besides, an institutional analysis tells us that an excess reliance on charity may possibly cause moral hazard or opportunistic behavior in the agent in the microfinance industry. Furthermore, strong reciprocators may fall into a dilemma, resulting in the hesitation of supporting the redistribution to the poor. The mainstream economists insist that market failure in credit market, such as credit rationing in equilibrium, can be caused by information asymmetries between lenders and borrowers. Institutional economists are concerned about the ill-designed incentive and sanction mechanism which may cause agency problems in credit market. Besides, we should argue that important market failure in Islamic microfinance can be caused by divergences in the degree of altruism and reciprocity of Muslim players in the industry.

In relation to the RDS case, the major financer of the institution is IBBL. We have shown that the asset-class of mainstream Islamic financial institutions (including IBBL, the largest of the country) is dominated by murabaha product. The product is based on markup price and does not involve with uncertainty. In contrast, financing MFIs relates to uncertainty but embodies the spirit of profit and loss sharing principles. This uncertainty can be accepted as business practice. However, uncertainty from agent's opportunistic behavior is unacceptable to principals. This circumstance creates a 'reciprocator's dilemma' in the perspective of IBBL in supplying fund to RDS. The mark up-based Murabaha (hunting a hare) might not be the optimum outcome for the mainstream financial institutions as well for the society but it does not require having too much trust on the actors' belief on divinity. On the other hand, pay-off would be more in financing MFIs (hunting a stag) but requires agents' devotion and faith on the life hereafter which cannot be known a priori. Principal's dominant strategy therefore, remains not to finance MFIs. That explains the current reality of Islamic MFIs worldwide. 


\section{Concluding comments}

International data and other anecdotal evidence suggest that there is a huge demand for Islamic microfinance across the globe. However, the supply side has apparently failed to meet the needs of rising demand. Various hypotheses can be raised and tested as possible reasons for this apparent failing. This paper however, focuses on the liability side of Islamic microfinance institutions. In general, capital will flow to the sphere of economy where it is most needed. But the nature of Islamic micro financing is that it is more of a philanthropic help than a pure profit motive. If so, it is unlikely that capital will eventually flow responding to the needs of the market demand. Microfinance institutions could not successfully convince donors to finance their activities. This failure can be attributed to various factors including the fact that Islamic scholars and policymakers have not been able to highlight the distinguished characteristics of Islamic financial model. Second, the fact that a significant portion of poor Muslims are reluctant to access to conventional micro financing is not properly recognized. Third, there are some among Muslim donors who hesitate to accept the contemporary mode of Islamic finance as properly Shari'ah compliant. Because of lack of representation or misrepresentation of facts embedded with Islamic finance, donors shy away from financing such schemes. At present, about one half of the total funding is supplied by the members themselves. Taking into account the funding capacity of those financially stranded population, it is understandable that their power to meet the social demand of micro financing will be an absolute meager and insufficient to eradicate poverty. Thus, shortage of funds is a critical constraint towards a growing Islamic microfinance.

On the other hand, lack of fund is seemingly a paradox in the sense that Islam encourages giving and spending for equality and justice in the society. Poverty eradication in the Muslim society is no less noble for faith community than another motives instructed in Islam. Citing some Qur'anic verses and Hadith as well as reviewing the existing literature, the paper has shown that the provision of altruism is very much pronounced in Islam. Islam fosters and encourages altruism. Thus, Muslims tend to support others based on trust and cooperation at personal cost. At the same time, they find it their duty to punish those who behave opportunistically even sometimes it personally costs them. As such, it is essential to know about the entrepreneur's faith and belief on the Day of Judgment which will drive his/her willingness to put sincere and honest efforts to make proper utilization of funds. However, trust of others on the divine punishment and rewards is impossible to know. Thus, possible funders are not willing to supply funds to entrepreneurs as long as other alternatives, which are not involved with uncertainty, are available. 
Of course, overcoming this problem is not an overnight issue. Moreover, the modern practice of Islamic financing is rather new. In this sense, a better system for enhancing microfinance activities can only be constructively adapted through a process of trial and error. Keeping this in mind, the following recommendations can be offered:

- Despite having various alternatives for altruistic activities in Islam, charity towards those who are in need of finance for starting a small business can certainly be considered. Towards this, the forum for Islamic microfinance can be established for creating awareness among those financially blessed by the Almighty to involve in charity through Islamic microfinance. At present, the conception of microfinance is confined merely to business. However, the charity aspect of it in terms of achieving equality in the society is also a critical aspect.

- Most importantly, besides relying on altruism and philanthropic sentiments of actors, national financial system should devise some provisions to avoid possibilities of opportunism so that any doubt in the mind of principals is abolished ex ante. It is understood that Muslim should comply with Islamic traditions and teachings. However, formal regulations for punishing those who may behave opportunistically will help them concentrating on microfinance-based charity more than they do in the absence of tangible rules. To realise this possibility, a proper Shari'ah board must be established who can certify the boarder scope of Islamic finance.

- Currently, most Islamic financial institutions are involved merely with Murabaha financing; however, they can be encouraged to focus also on social justice and equality through philanthropic financing towards the poor in the form of microfinance.

- In designing appropriate institutions, emphasis can be put on how to realize the Zakat fund for micro-financing. The mobilisation of compulsory almsgiving is very miniscule in all Muslim countries across the world despite having a high potential as a source of fund for micro-financing. Only proper initiatives can make this possibility into a reality.

\section{Notes}

* Yasushi Suzuki is Professor of Graduate School at International Management Ritsumeikan Asia Pacific University, Japan. His email is szkya@apu.ac.jp

** Mohammad Dulal Miah is Assistant Professor at College of Economics, Management and Information Systems, University of Nizwa, Oman. His email is dulal@unizwa. edu.om 
1. I refer to The Holy Qur'an, Arabic Text and English Translation (2010), $9^{\text {th }}$ printing, Noor Foundation International Inc.

\section{References}

Ahmad, H. 2007. Waqf Based Microfinance: Realizing The Social Role of Islamic Finance, paper presented in the International Seminar on Integrating Awqaf in the Islamic Financial Sector, held on March 6-7, Singapore.

Arif, G. Farooq, S. 2011. Poverty, Inequality and Unemployment in Pakistan. Background Paper for the IDB Group MCPS Document for Pakistan. Pakistan Institute of Development Economics and Islamic Develpment Bank, October 2011.

Arrow, K. 1974. The Limits of Organization. Norton.

Ayub, M. 2007. Understanding Islamic Finance. J. Wiley \& Sons Ltd, Chichester.

Bangladesh Microfinance Statistics. 2013. Development of microfinance sector in Bangladesh, Microcredit Regulatory Authority

Bowles, S. 2012. The New Economics of Inequality and Redistribution. Cambridge University Press, New York.

Bowles, S. Gintis, H. 2011. A Cooperative Species: Human Reciprocity and Its Evolution. Princeton University Press, Princeton.

Çizakça, M. 2011. Islamic Capitalism and Finance: Origins, Evolution and the Future. Edward Elgar, Chelthenham.

Cohen, D. Knetsch, D. 1992. Judicial choice and disparities between measures of economic values, Osgoode Hall Law Review, Vol. 30, Pp: 737-770

Durrani, M. 2006. Business ethics and venture capital in Islam in Venture Capital, Islamic Finance and SMEs: Valuation, Structuring and Monitoring Practices in India, Durrani M, Boocock G (ed.). Palgrave; Pp.148-169.

Eissa, G. 2013. Microcredit as a strategy for poverty reduction: A Case Study of the Sudan. Journal of Modern Accounting and Auditing 9(4): 557-570

Elsiefy, E. 2013. Towards a Model for Islamic Venture Capital. International Journal of Modern Business Issues of Global Market 1(1):39-56

El-Zoghbi, M. Tarazi, M. 2013. Trends in Sharia-Compliant Financial Inclusion. Focus Note \# 84, CGAP

Fong, C. M. 2007. Evidence From An Experiment On Charity To Welfare Recipients: Reciprocity, Altruism, And The Empathic Responsiveness Hypothesis. The Economic Journal, Vol. 117, Pp. 1008-1024 
Fukuyama, F. 1995. Trust: The Social Virtues and the Creation of Prosperity. The Free Press, New York.

Green, W. S. 2005. Introduction: Altruism and the Study of the Religion", In Altruism in World Religions, Nuesner, J., and Chilton, B., (eds.), Washington: Georgetown University Press

Hamada, M. 2010. Commercialization of Microfinance in Indonesia: The Shortage of Funds and The Linkage Program. The Developing Economies 48(1):156-176

Hammond, P.1975. Charity: Altruism Or Cooperative Egoism? In Edmund, S. P. (ed.), Altruism, Morality, and Economic Theory, NY: Russell Sage, Pp. $115-131$

Hassan, K. 2010. An Integrated Poverty Alleviation Model Combining Zakat, Awqaf, And Microfinance, paper presented at Seventh International Conference on The Tawhidi Epistemology: Zakat and Waqf Economy, held in Bangi, Malaysia.

Homerin, L. E. 2005. Altruism in Islam, in Altruism in World Religions, Nuesner, J., and Chilton, B., (eds.), Washington: Georgetown University Press, Pp. 6787

Imai, K. Azam, S. 2010. Does Microfinance Reduce Poverty in Bangladesh? New Evidence From Household Panel Data, Economics Discussion Paper Series \# 1019, University of Manchester

Karim, N. Tarazi, M. and Reille, X. 2008. Islamic Microfinance: An Emerging Market Niche. Focus Note 49, CGAP.

Khaled, M. 2011. Building a Successful Business Model For Islamic Microfinance, Global Microcredit Summit Commissioned Workshop Paper, Valladolid, Spain

Khalil, E. L. 2004. What is Altruism? Journal of Economic Psychology, Vol. 25, No. 1 , Pp. 97-123

King, J. 2015. The Islamic Microfinance Challenge, The Banker (published on January 5, 2015)

Looft, M. 2014. Inspired Finance: The Role of Faith in Microfinance and International Economic Development. Palgrave Macmillan, Basingstoke.

Mawdudi, S. 2011. First Principles of Islamic Economics, translated by Ahmad Imam Shafaq Hashemi. The Islamic Foundation, Leicestershire.

Nagel, T. 1970. The Possibility of Altruism. Princeton University Press, Princeton. Naqvi, S. 2003. Perspectives on Morality and Human Well-Being, The Islamic Foundation, Leicestershire. 
Suzuki, Y. 2013. A Post-Keynesian Perspective on Islamic Prohibition of Gharar. International Journal of Islamic and Middle Eastern Finance and Management 6(3): 200-210.

Suzuki, Y. Barai, M. and Uddin, S. 2013. Islamic Banking and the Grameen Mode of Microcredit in Bangladesh: An Institutional Comparison. Contemporary South Asia 21 (4): 413-428.

United Nations Development Programme (UNDP). 2012. Scaling up Islamic Microfinance In Bangladesh Through The Private Sector: Experience of Islamic Bank Bangladesh Limited (IBBL). Poverty Reduction: Scaling Up Local Innovations For Transformational Change.

Williamson, O. 1985. The Economic Institutions of Capitalism. The Free Press, New York.

Yosoff, W. S. 2014. Industrial Economics and Organization: Conventional and Islamic Perspective, University Insaniah

Yumna, A. Clarke, M. 2011. Integrating Zakat And Islamic Charities With Microfinance Initiative In The Purpose Of Poverty Alleviation in Indonesia. $8^{\text {th }}$ International Conference on Islamic Economics and Finance. 